
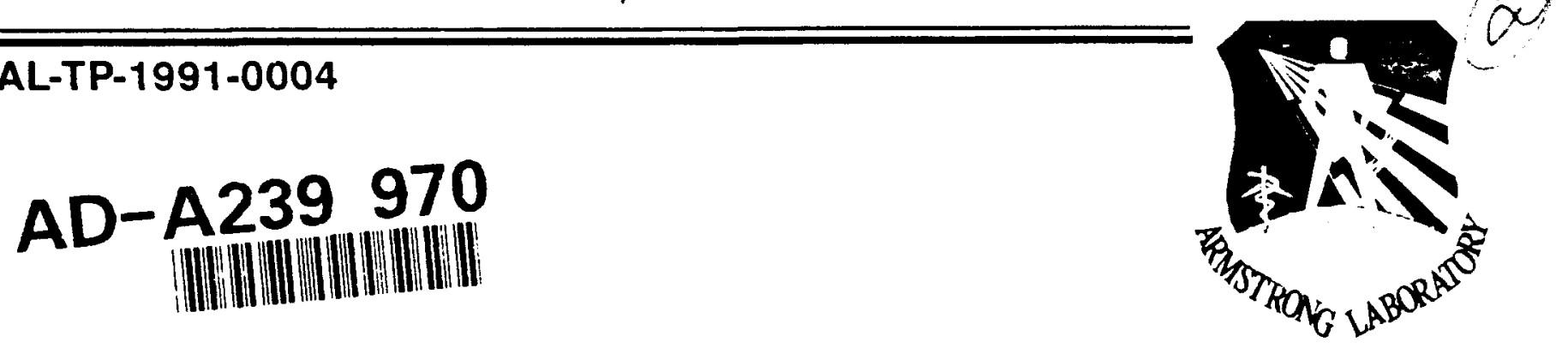

\title{
MAXIMIZING ACHIEVEMENT IN COMPUTER-BASED TRAINING (CBT): THE ROLE OF THE INSTRUCTOR AND OTHER VARIABLES
}

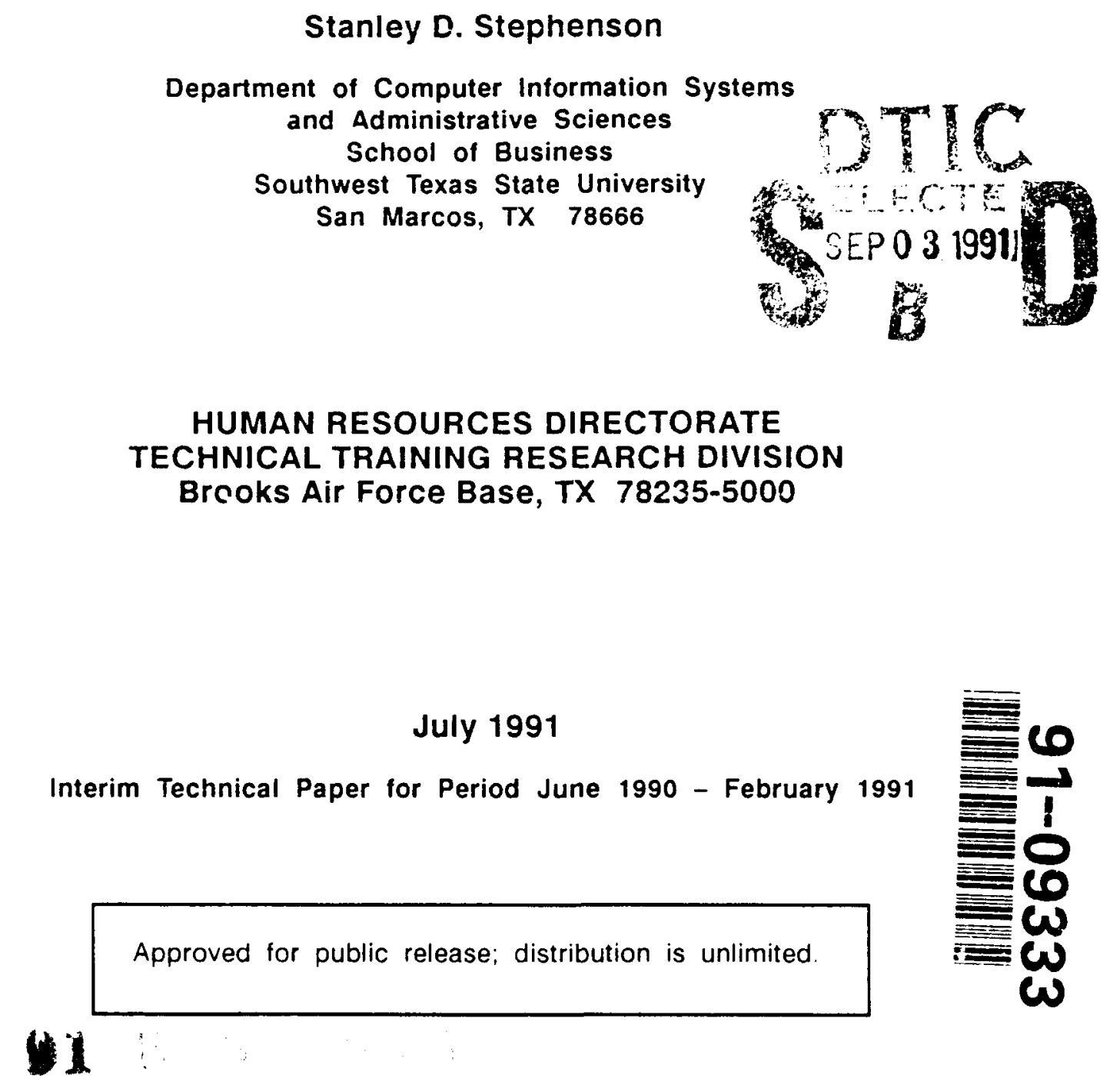

AIR FORCE SYSTEMS COMMAND

BROOKS AIR FORCE BASE, TEXAS 78235-5000 


\section{NOTICES}

When Government drawings, specifications, or other data are used for any purpose other than in connection with a definitely Government-related procurement, the United States Government incurs no responsibility or any obligation whatsoever. The fact that the Government may have formulated or in any way supplied the said drawings, specifications, or other data, is not to be regarded by implication, or otherwise in any manner construed, as licensing the holder, or any other person or corporation; or as conveying any rights or permission to manufacture, use, or sell any patented invention that may in any way be related thereto.

The Public Affairs Office has reviewed this paper, and it is releasable to the National Technical Information Service, where it will be available to the general public, includina foreign nati,na!s.

This paper has been reviewed and is approved for publication.
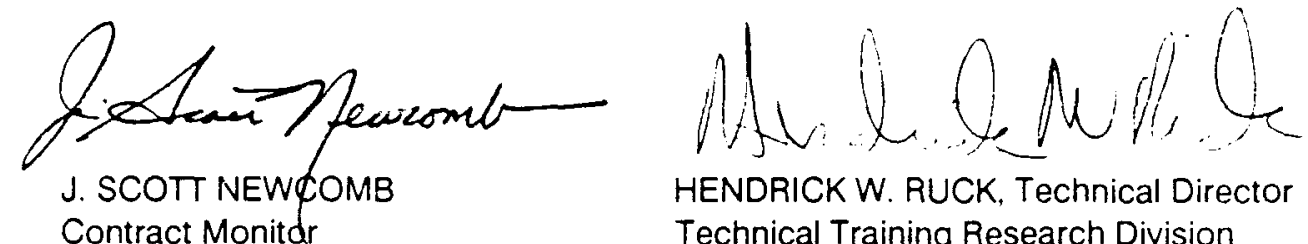

HENDRICK W. RUCK, Technical Director Technical Training Research Division

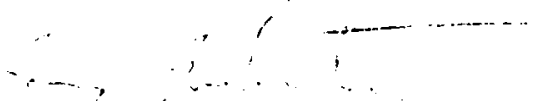

RODGER D. BALLENTINE, Colonel, USAF

Chief, Technical Training Research Division 


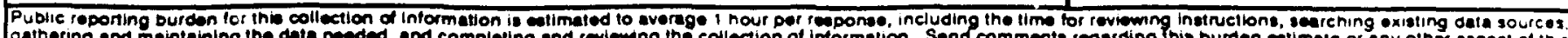

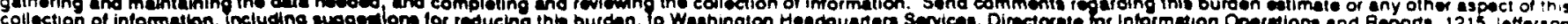

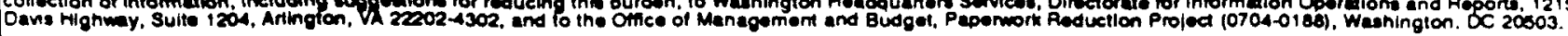

\begin{tabular}{|c|c|c|}
\hline 1. AGENCY USE ONLY (Loavb blank) & $\begin{array}{c}\text { 2. REPOAT DATE } \\
\text { July } 1991\end{array}$ & $\begin{array}{c}\text { 3. REPOAT TYPE AND DATES COVERED } \\
\text { Interim - June } 1990 \text { - Fobruary } 1991\end{array}$ \\
\hline
\end{tabular}

\begin{tabular}{|l|l} 
4. TITLE AND SUBTITLE & 5. FUNDINO NUMBEAS
\end{tabular}

Maximizing Achievement in Computer-Based Training (CBT): The Role of the Instructor and Other Variables

C - F49620-88-C-0053

PE - 62205F

PR - 1121

6. AUTHOR(S)

Stanley D. Stephenson

TA - 10

WU - 66

7. PERFORMING ORGANIZATION NAME(S) AND ADDRESS(ES)

Department of Computer Information Systems and Administrative Sciences

8. PERFOAMING ORGANIZATION

School of Business

Southwest Texas State University

San Marcos, TX T860́o

9. SPONSORING/MONITORING AGENCY NAMES(S) AND ADDRESS(ES)

Armstrong Laboratory

Human Resources Directorate REPORT NUMBER

Technical Training Research Division

Brooks Air Force Base, TX 78235-5000

11.SUPPLEMENTARY NOTES

Armstrong Laboratory TEuhnical Monitor: J. Scott Newcomb, (512) 536-3992

128. DISTAIBUTION/AVALABILITY STATEMENT

Approved for public release; distribution is unlimited.

13. ABSTRACT (Maximum 200 words)

The role of the instructor in the computer-based training (CBT) environment has typically not been researched. Recent studies have shown that the behavior and the attitude of the instructor can affect achievement in CBT. Moreover, the importance of the instructor in traditional instruction (TI) settings has been well established. This paper summarizes the important functions served by the effective $T I$ instructor and discusses how these functions can be provided in CBT. The paper concludes with recommendations as to how to structure the CBT environment to ensure that achievement is maximized.

:4. SUBNECT TEAMS computer-based training (CBT) instruction instructor role

instructor-student interaction
10. SPONSORING/MONITORING AGENCY REPORT NUMBER

AL-TP-1991-0004

12b. DISTRIBUTION CODE

\begin{tabular}{|c|c|c|c|}
\hline $\begin{array}{l}\text { 17. SECUATY CLASSIFICATION } \\
\text { OF AEPOFT } \\
\text { Unclassified }\end{array}$ & $\begin{array}{l}\text { 18. SECUAITY CLASSIFICATION } \\
\text { Of THIS PAGE } \\
\text { Unclassified }\end{array}$ & $\begin{array}{l}\text { 19. SECUAITY CLASSIFICATION } \\
\text { OF ABSTRACT } \\
\text { Unclassified }\end{array}$ & $\begin{array}{l}\text { 20. LMITATION OF ABSTRACT } \\
\text { UL }\end{array}$ \\
\hline
\end{tabular}




\section{TABLE OF CONTENTS}

SUMMARY

Page

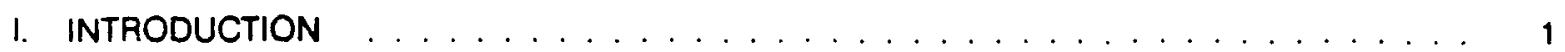

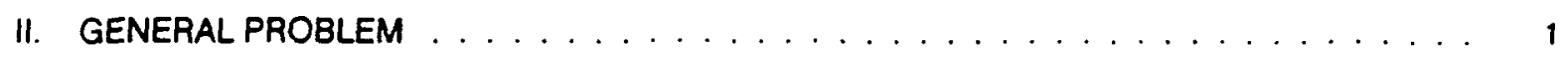

III. THE EFFECTIVE INSTUCTOR IN TRADITIONAL INSTRUCTION . . . . . . . . . . . . 2

IV. CBT INSTRUCTOR CONTROL OF EFFECTIVE TI INSTRUCTOR FUNCTIONS $\ldots \ldots \ldots$

V. THE EFFECTIVE CBT INSTRUCTOR'S ROLE, BEHAVIOR, AND ATTITUDE . . . . . . . . 4

VI. CONTROL OF REMAINING EFFECTIVE TI INSTRUCTOR FUNCTIONS IN CBT . . . . . . . 5

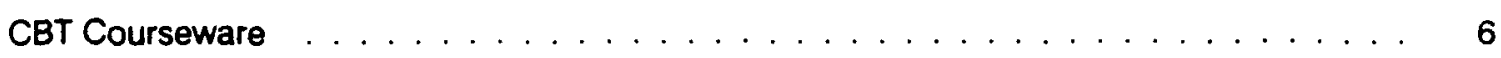

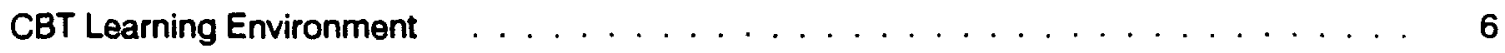

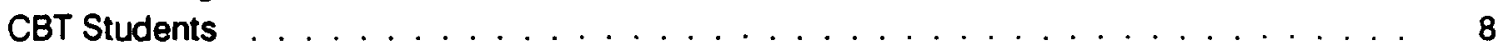

VII. OTHERFACTORS $\ldots \ldots \ldots \ldots \ldots \ldots \ldots \ldots \ldots$

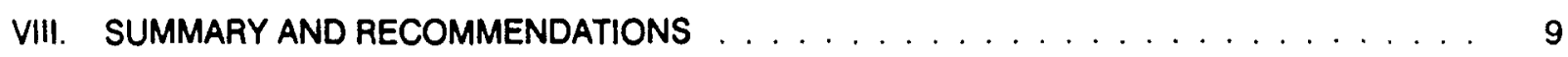

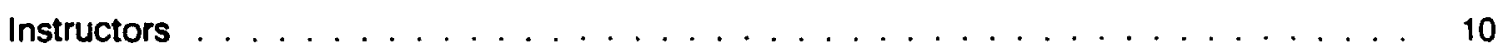

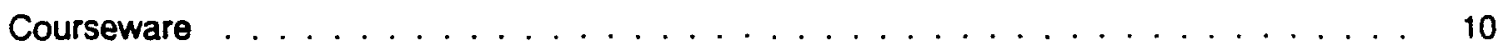

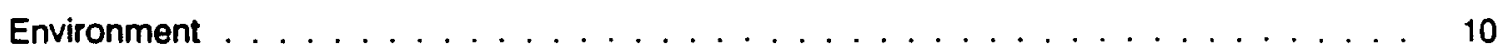

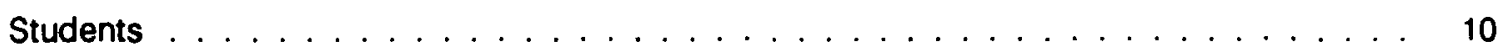

Other .............................. 10

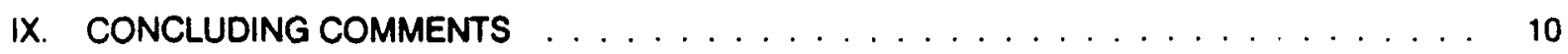

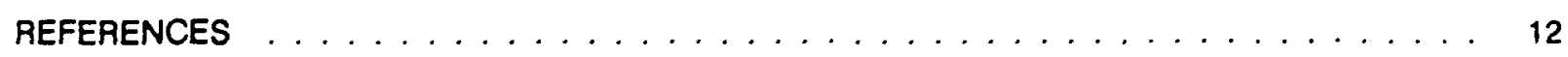

\section{LIST OF TABLES}

Table

1 TI Instructor Functions Positively Related to Achievement $\ldots \ldots \ldots \ldots \ldots \ldots$

i TI Instructor Functions Negatively Related to Achievement . . . . . . . . . . . . . . . 2

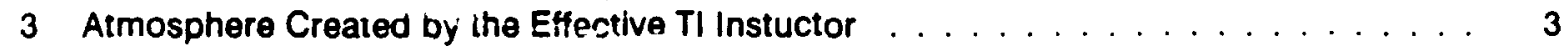

$4 \mathrm{TI}$ Instructor Functions Controlled by the CBT Instructor . . . . . . . . . . . . . 4

5 TI Instructor Functions Not Controlled by the CBT Instructor . . . . . . . . . . . 5

$6 \mathrm{TI}$ Instructor Functions Controlled by CBT Courseware . . . . . . . . . . . . . . 6

7 Tl Instructo: Funntinns ivigt Controllan by Eithar the Inatrujtor or the Courseware in CBT 


\section{PREFACE}

This paper summarizes current research and thinking on the role of the instructor in computer-based training (CBT). It concludes with recommendations on how to ensure that effective traditional instruction instructor variables are incorporated into the CBT environment. This research was conducted under the United States Air Force Summer Faculty/Graduate Student Research Program and was sponsored by the Air Force Office of Scientific Research/AFSC. United States Air Force, under contract F49620-88-C-0053. The author would like to thank the Armstrong Laboratory's Human Resources Directorate, and in particular the Technical Training Research Division AL/HRT for providing an environment supportive of this work. Several AL/HRT individuals were of specific help: Colonel Rodger Ballentine; and Drs. Scott Newcomb, and Hendrick Ruck. To the resi of the Division and also to the Library staff, thanks for your assistance.
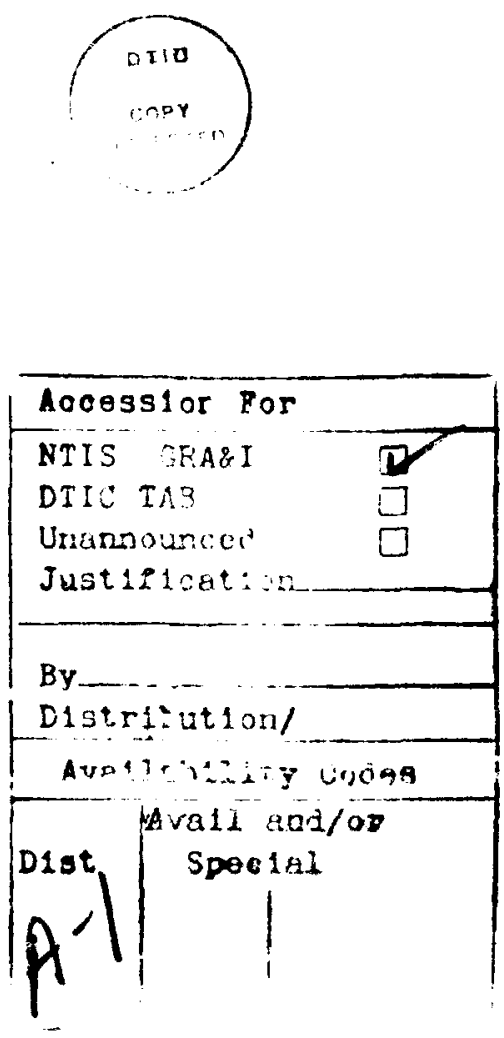
MAXIMIZING ACHIEVEMENT IN COMPUTER-BASED TRAINING (CBT): THE ROLE OF THE INSTRUCTOR AND OTHER VARIABLES

\section{SUMMARY}

The role of the instructor in the computer-based training (CBT) environment has typically not been researched. Yet, recent studies have shown that the behavior and the attitude of the instructor can affect achievement in CBT. Moreover, the importance of the instructor in traditional instruction (TI) settings has been well documented. This paper summarizes the important functions served by the effective TI instructor and discusses how these functions can be provided in CBT. The paper concludes with recommendations on how to structure the CBT environment to ensure that achievement is maximized.

\section{INTRODUCTION}

In a series of papers on computer-based training (CBT) (which is used here as a generic term for all types of computer-based training/learning/assistance), Stephenson (1989, 1990a, 1990b) discussed issues associated with the CRT instructor. In traditional instruction (TI) the functions of an effective instructor are well known (Brophy, 1986; Brophy \& Good, 1986; Rosenshine, 1983). The role of the CBT instructor, however, is essentially undefined because this area is rarely considered in CBT research. This lack of consideration is perhaps based on an underlying assumption that a properly designed CBT system does not require an instructor. Yet recent research has shown that the attitude and the behavior of a CBT instructor can influence achievement (Moore, 1988; Stephenson, 1990c).

If it can be assumed that even in the most automated CBT situation there will be some sort of instructor or course administrator present in the learning facility, then the role of that individual should be defined. Responsibility for student success cannot simply be turned over to CBT with the expectation that by itself it will produce maximum results.

The purposes of this paper are twofold. First, this paper attempts to define the role of the CBT instructor with regard to achievement. Second, it suggests how the total CBT environment can be configured so that appropriate, effective $\mathrm{TI}$ instructor functions are provided in CBT.

\section{GENERAL PROBLEM}

There is a relatively high degree of consensus as to what an effective $\mathrm{Tl}$ instructor does versus what a not-so-effective $\mathrm{TI}$ instructor does (Brophy, 1986; Brophy \& Good, 1986; Rosenshine, 1983). Early CBT research (McCombs, Back, \& West, 1984; McCombs \& Lockhart, 1984) also concluded that the role of the instructor was critical with regard to the success of CBT. Yet there is still little agreement or even discussion as to what an effective CBT instructor does. Because the role of the CBT instructor has not been adequately addressed, CBT implementors do not have a clear understanding as to what that role should be, even though research has shown that the CBT instructor can make a difference with regard to achievement (Moore, 1988; Stephenson, 1990c).

In addition, there is also the possibility that $\mathrm{Tl}$ instructors are hesitant to even adopt CBT simply because they do not know what their role will be. Rather than venturing into the unknown, instructors resist changing from $\mathrm{Tl}$ to CBT. Moreover, it has been shown that the success or failure of the entire CBT system can be in part a function of the instructor (McCombs et al., 1984). 
This paper will address the issue of the instructor's role in CBT. For discussion purposes, this paper will use a formal (versus on-the-job), completely automated CBT system. Although such a CBT system exists in only a few instances, using a completely automated CBT system will permit the reader to adapt this discussion to the specifics of his or her individual CBT system.

\section{THE EFFECTIVE INSTRUCTOR IN TRADITIONAL INSTRUCTION}

Majz: reviews by Brophy (1986), Brophy and Good (1986), and Rosenshine (1983) have summarized those $\mathrm{Tl}$ instructor behaviors which seem to sigrificantly impact student achievement. These reviews produced a general agreement about those $\mathrm{TI}$ behaviors which are positively or negatively linked to academic gain. The results are presented in Tables 1 and 2, respectively.

Taide 1. TI Instructor Functions Positively Related to Achievernemt

\begin{tabular}{l}
\hline Knowledge about course content demonstrated \\
Businesslike atmosphere created \\
Organized atmosphere created \\
Focus placed on academics \\
Praise (for task performance) given to students \\
Mild reproach given to students \\
Neutral feedback given to students \\
High percentage of time spent on-task \\
Student behavior controlled (academic) \\
Student behavior controlled (non-academic/physical) \\
Students warned versus threatened over misconduct \\
Questions asked \\
Feedback on task performance provided \\
Student behavior monitored \\
Attitude created that students are accountable for their \\
performance/achievement \\
Frequent but short interactions held \\
Presentations are clear, structured, and organized
\end{tabular}

\section{Table 2. TI Instructor Functions Negatively Related to Achievernent}

\begin{tabular}{l}
\hline \hline Strong criticism given to students \\
Negative climate created \\
Non-response questions asked \\
Time spent on non-academics \\
Affective nature of course emphasized \\
Instructor does not interact with students \\
Use of silent reading, independent study, or written assignments
\end{tabular}

In addition to the specific functions listed in Tables 1 and 2, the literature suggests that a critical aspect of a successful (i.e., high academic achievement) TI classroom is the atmosphere established by the course instructor. Table 3 summarizes the high achievement classroom atmosphere created by the effective $\mathrm{TI}$ instructor. 
The general conclusions from the effective $\mathrm{TI}$ instructor research are that the instructor is very much a proactive, task-oriented, internal-locus-of-control individual. The effective instructor knows the course material, spends a high percentage of time on-task, controls the environment, praises students for task performance, and frequently interacts with the students on a one-to-one basis. As might be expected, effective $\mathrm{Tl}$ instructors also present the course material in an appropriate manner; i.e., their presentations are clear, structured, and crganized.

\section{Table 3. Atmosphere Created by the Effective $\pi$ Instructor}

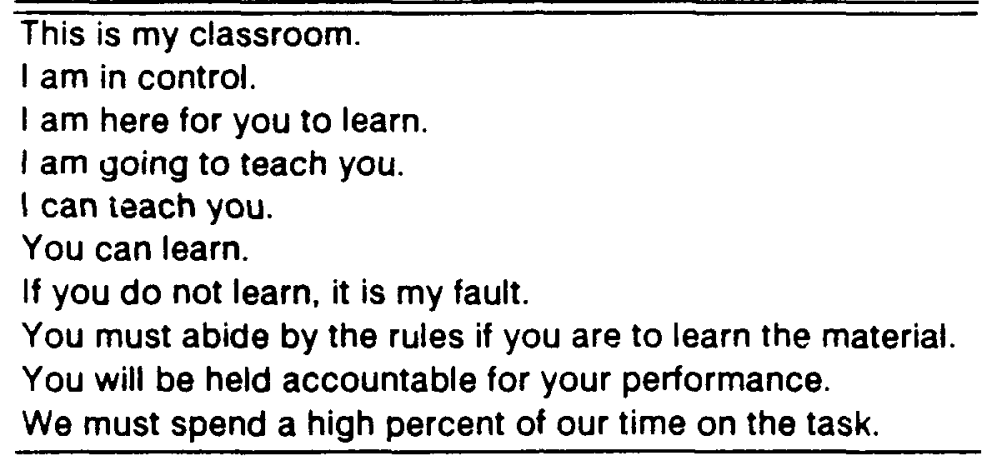

\section{CBT INSTRUCTOR CONTROL OF EFFECTIVE TI INSTRUCTOR FUNCTIONS}

Stephenson (1990b) suggested that effective TI instructor functions are dichotomized in CBT. Effective ?I instructor variables related to presenting the course material are primarily (but not exclusively) allocated to the CBT courseware whereas class management variables are primarily allocated to the CBT instructor. Therefore, it appears that in CBT (versus Ti) the instructor's role has shifted from that of content presenter and course administrator to that of course administrator.

If such a shift has occurred, then the number of instructor-controlled functions which can affect student achievement is reduced in CBT. Instead of being able to manipulate both course material presentation and classroom management variables, CBT instructors primarily have classroom management variables at their disposal. Table 4 summarizes those effective $\mathrm{TI}$ instructor functions which the CBT instructor still controls. Moreover, the CBT instructor still controls the classroom atmosphere variables listed in Table 3.

CBT instructors obviously have a major problem. They are still responsible for student success, but they are not in charge of presenting the material. They cannot, for example, motivate students with exciting lectures about the course material. Yet the instructor is still responsible for motivating the students. Consequently, it becomes imperative that CBT instructors realize the limitations which CBT places on them but also realize that student success remains their responsibility.

A: this point, "Use of silent reading, independent study, or written assignments" should be discussed. This negattve function (I.e., research has shown that $\mathrm{TI}$ instructors who employ this behavior produce lower leve!s of achievement than do TI instructors who do not use this behavior) is one which the CBT instructor must address.

In one sense, it could be argued that CBT is in fact composed of silent reading, independent study, and written assignments. It could also be argued that it is not "silent reading" that is the issue; rather, the issue is that $\mathrm{TI}$ instructors who use this form of instructing also employ other forms of poor instruction. Either they do not know the material or they do not know how to teach it. Moreover, such an approach in TI conveys to the student that the instructor either does not care about teaching or does not have the capability to teach. 
Table 4. $\pi$ Instructor Functions Controlled by the CBT Instructor

\begin{tabular}{l}
\hline Positive \\
Knowledge about course content demonstrated \\
Businesslike atmosphere created \\
Organized atmosphere created \\
Focus placed on academics \\
High percentage of time spent on-task \\
Student behavior controlled (non-academic/physical) \\
Students warned versus threatened over misconduct \\
Student behavior monitored \\
Attitude created that students are accountable for their \\
performance/achievement \\
Negative \\
Strong criticism given to students \\
Negative climate created \\
Time spent on non-academics \\
Affective nature of course emphasized \\
Use af silent reading, independent study, or written assignments
\end{tabular}

If CBT instructors simply turn instruction over to $C B T$, they risk having their students form the same attitude they form of $\mathrm{Tl}$ instructors who turn instruction over to "silent reading." Preventing the formation of this negative attitude is obviously a responsibility of the CBT instructor. That is, because CBT is in effect "silent reading," CBT instructors must convey to their students that the computer is being used to provide instruction because use of the computer is in the best interest of the students' achievement. In a sense CBT instructors are forced into admitting that CBT can do a better job of instructing than they can, an uncomfortable situation at best.

\section{THE EFFECTIVE CBT INSTRJCTOR'S ROLE, BEHAVIOR, AND ATTITUDE}

Even though CBT instructors are no longer directly presenting the course content, they still have responsibility for the students' achievement. Therefore, CBT instructors must do the following:

1. Assume responsibility for learning

- motivate students

- maintain students' interest

- maintain students' attention/arousal

- convey attitude that CBT is being used to maximize achievement

2. Insure high time-on-task

- minimize transition time

- conduct quick start-up

- stay on task untll the end of class

- be organized

- be proactive (prevent versus solve problems) 
3. Create the proper learning environment/ethos

- emphasize pro-pertormance versus pro-compliance

- control physical setting

- create attitude in students that they are responsible for their performance

Moreover, the CBT instructor must be (a) positive, with a can-do/must do attitude; (b) task-oriented; (c) an iniernal-locus-of-control individual; (d) warm; and (e) knowledgeable about the subject material and the CBT system.

Notable by its absence in this ciscussion is the requirement for the instructor to be a good platform lecturer. In CBT this skill is not necessary, need not be an instructor selection criterion, and should not be used in the instructor evaluation system. Good instructors in CBT are those who are effective in that environment; i.e., they must fully manipulate the achievement-related attitudinal and classroom atmosphere variables still under their control so as to maximize achievement. These instructors must recognize that they are no longer instructors in the traditional sense, but they must also recognize that they are still responsible for student success. Therefore, they must use the achievement-related variables and control them to best advantage.

\section{CONTROL OF REMAINING EFFECTIVE TI INSTRUCTOR FUNCTIONS IN CBT}

To ensure that achievement is maximized in CBT, all of the functions performed by the effective $\mathrm{TI}$ instructor must be accounted for in CBT. Those functions listed in Tables 1,2, and 3 which are not controlled by the instructor in a completely automated CBT system . CBT-instructor-controlled functions are listed in Table 4) must be controlled by some other aspect of the CBT environment. The remaining effective $\mathrm{TI}$ instructor functions are listed in Table 5.

Table 5. TI Instructor Functions Not Controlled by the CBT Instructor

\begin{tabular}{l}
\hline Positive \\
Praise (for task performance) given to students \\
Mild ieproach given to students \\
Neutral feedback given to students \\
Student behavior controlled (academic) \\
Questions asked \\
Fsedback on iask performance provided \\
Frequent but short interactions held \\
Presentations are clear, structured, and organized
\end{tabular}

\section{Negative}

Non-response questions asked No interaction between instructor and students

CBT is actually composed of four components: the total CBT environment (which includes the hardware), the courseware, the CBT instructor, and the student. By manipulating these four components, all effective $\mathrm{TI}$ instructor functions can be provided in CBT. Effectlve $\mathrm{TI}$ functions controlled by the CBT instructor have been discussed in Seccions IV and ". The interaction between 


\title{
CBT Courseware
}

The CBT courseware has the primary responsibility for presenting the course material. Therefore, those functions listed in Table 6 are the direct responsibility of the CBT courseware designer. CBT designers must erisure that these functions are considered in the development of CBT courseware.

\section{Table 6. $\pi$ Instructor Functions Controlled} by CBT Courseware

\author{
Positive \\ Questions asked \\ Presentations are clear, structured, and organized
}

Negative

Non-respor, e questions asked

The CBT courseware component has two additional responsibilities. First, research (Stephenson, 1990c) has shown that instructoi-student interaction can affect student success. Therefore, CBT designers should ensure that interaction is built into the courseware. Second, research has also shown that low-ability students seem to benefit more from instructor interaction than do high-ability students (Stephenson, 1990c) and th at CBT instructors spend more time with luw-ability students (Schofield. Evans-Rhodes, \& Huber, 1989). Low-ability students also have different attitudes about C.8T, depending on their gender (Dalton, Hannafin, \& Hooper, 1989). Low-ability students may be the group CBT can primarily impact, provided other factors such as instructor interaction are fresent. If student ability is not known, CBT designers should build ability assessment into the courseware so that instructors can quickly identify low-abiity students. Once these students are identified, instruciors can direct more of their individual assistance towarc these students in order to ha: $:$ thie greatest impact on group achievement.

Those TI instructor functions still not accounted for by either the CBT instructor or the CBT courseware are presented ir Table 7. These functic. 5 s pose a problem for CBT in that they have been shown to influence achievement in $\mathrm{TI}$, but they are essentially not accounted for in CBT. That is, because these functions are not provided by either the CBT instructor or the courseware, they may not be present in CBT. The functions listed in Table 7 must be controlled in some way other than by the CBT instructor or the CBT courseware.

\section{CBT Learning Environment}

The functions listed in Table 7 can be controlled in CBT by properly manipulating the CBT learning environment. In particular, if students work CBT in dyads or triads, these functions will be assumed by the students themselves. That is, feedback (praise, neutral, and mild reproach) anc social interac sicin will be provided by the other member(s) of the dyad/triad. Justification for this configuration of the CBT environmert coras from two sources. First, there is a body of TI literature on the effect of students working in groups versus working individually. Much of the group work has focused on the effect of cooperation versus competition. The general consensus is that students working in small groups produce hirg her achievement than do students working alone, especially in a cooperative setting (Johinson, Johnson, \& Stanne, 1985; Warring, Juhnson, Maruyama, \& Johnson, 1985; Yager, Johnson, \& Johriann, 1985). The optimal group size s ims to be either two or three (Cox \& Berger, 1985; Trowbridge \& Durnin, 1984; Webb, 1987). There is also a general consensus that paired students should be of like gender and have similar abilities (Dalton, 1990; Dossett \& Hulvershorn, 1983; Hooper, Ward, Hannafin, \& Clark, 1989; Johnson et al., 1985). 


\section{Table 7. TI Instructor Functions Nol Controlled by Either the Instructor or the Courseware in CBT}

\begin{tabular}{l}
\hline Postive \\
Praise (for task perfcrmance) given to students \\
Mild reproach given to students \\
Neutral feedback given to students \\
Fetdback on task performance jrovided \\
Frequent but short interactions held \\
Negative \\
No interaction between instructor and stildents
\end{tabular}

The second justification for arranging students in groups in CBT comes from recent CBT research. There is a general consensus that the achievement of students working CBT in dyads or triads is equal to or surpasses the achievement of students working alone (Carrier \& Sales, 1987; Cox \& Berger, 1985; Dalion, 1990; Dalton et al., 1989. Dossett \& Hulverst.orn, 1983; Hmelo, 1989; Johnson, Johnson, \& Stanne, 1986; Justen, Waldrop, \& A.ciams, 1990; Shull, 1990; Trowbridge \& Durnin, 1984; Webb, 1987). "No study has reported significantly greater learning when students work alone" (Webb, 1987, p. 195).

There are many advantages associated with arranging students in groups. From a pragmatic view, more students can be irained by working in teams than working alone. Students gain ideas and information from each other. Students learn from other team members' actions. Team members give each other support, reinforcement, and feedback. Regardless of how well the CBT courseware is written, there will always be some portion that is uncleai. Students working in teams are more !ikely to arrive at the correct concli'sion as to what the courseware authors actually intended. In sum, team members perform many of the functions of an instructor in a conventional setting; in fact, communication among students may be more effective than communication between students and an instructor (Webb, 1987).

Several authors have suggested two caveats to these findings. First, if the results show that students in groups outperform students working alone, why are there not more group-learning settings? A suggested answer is that teachers have not been taught to teach students arranged in groups (Talmage Pascarella, \& Ford, 1984). No matter what the research literature shows, if the classroom teacher is not comfortable with groups, students will not be arranged in groups. Second, students are not used to working in groups (Datton, 1990). Unless prepared to work as a group, students ussigned to work CBT in teams may resort to social loafing or othei off-task behavior.

In summary, there seems to be strong support for having students wurk CBT in dyads or triads. Moreover, CBT may be a more logical environment for study groups than is $\mathrm{TI}$. In TI, grouped students are in conflict with the norm of working alone. Also, working in groups -equires a det.lnite change for the $\mathrm{Tl}$ instructor. However, "here is no established norm in CBT; therefore, working in study teams is as logical as working alone. Plus, working CBT in groups versus alone has relatively no impact on the instructor.

The bottom line seems to be that proper arrangement of the CBT environment permits the functions listed in Table 7 to be accounted for in CBT. Therefore, all of the $\mathrm{TI}$ instructor functions listed in Tables 1,2 , and 3 can be accounted for in CBT. 


\section{CBT Students}

CBT designers often fail to consider the role of the student, and to simply assume that the CBT student's role does not change. However, the dramatic changes in the delivery system do not go unnoticed by the student. To properly transition students into CBT, they should be adequately prepared. For instance, they should feel comfortable with the delivery system prior to beginning training. This would include, of course, being comfortable with a computer. That is not to suggest that students need to know how to program, (e.g., in BASIC), but it does suggest that, at a minimum, students should know how to keyboard, if not type. At some point, the computer terminal must become to the student simply a necessary piece of equipment whose internal workings need not be understood. Moreover, if the students are to be arranged in study teams, as suggested above, then students need to be trained in how to act as a team. Most students have a lifelong history of working by themselves and have had little experience working in cooperation. It is unreasonable to assume they will easily adapt to working in teams without preparation.

CBT impacts students as well as other components of the learning system, and students must be properly prepared. Such preparation takes time, money, and effort. However, by admitting that extra time, money, and effort must be spent on student preparation, CBT advocates leave themselves open to the criticisms expressed by Clark (1983), Hagler and Knowiton (1987), and Johnson et al. (1985). These and other authors point out that if the same amount of time, money, and effort were put into improving an existing $\mathrm{TI}$ system, increased performance and reduced learning time might result in that environment also.

\section{OTHER FACTORS}

Several other factors related to the CBT environment should also be discussed. If students are going to be organized into study teams, the teacher must be proficient at working with these teams. It was previously pointed out that students have a history of working alone. Instructors have a similar background. Therefore, not only must instructors be prepared to transition to CBT, they must also be prepared to transition to an environment in which students are interacting among themselves.

If students are going to be working CBT in teams, the courseware should take this into account. CBT software should be written to acknowledge that more than one student is at the terminal; e.g., the courseware should be written to require a response from each team member.

CBT instructors must also be prepared to spend more of their time with low-ability students. Low-ability students seem to benefit least from CBT, at least for learning course material with some degree of difficulty (Adams, Waldrop, Justen, \& McCrosky, 1987; Hatlva \& Shorer, 1989; Klein \& Keller, 1990: Stephenson, 1990c; Whitney \& Urquhart, 1990). However, instructor interaction seems to have a positive effect on low-ability students in CBT (Schofield et al., 1989; Stephenson, 1990 c); i.e., increased instructor Interaction increases student achievement. Moreover, instructors who have transitioned from $\mathrm{TI}$ to CBT report that they spend more time with low-ability students in CBT than they did in $\mathrm{Tl}$ (Schotield Gt al., 1989).

Instructor preparation is obviously very critical to the success of CBT. instructors must be knowledgeable roncerning the operation of the CBT system. CBT instructors also need to be aware that they are going to be supervising study teams and that they are going to be spending more one-on-one time with low-abllity students.

CBT implementors should not assume that $T I$ instructors know all of the above. Upon being placed in CBT, most TI instructors will act as they have always acted in the TI classroom. However, different skills are needed in CBT. CBT instructors must be selected, trained, and evaluated using criteria from CBT. Moreover, CBT implementors should realize that the role of the instructors' supervisors will change. Supervisors may try to evaluate CBT instructors by means of the more familiar TI criteria 
rather than effective CBT criteria. "Interestingly, the chairman of the math department mentioned to our project staff that he could not evaluate teachers using the intelligent tutors (CBT) very well since those classes were run so differently from ordinary ones and different teaching skills were needed" (Schofield et al., 1989, p. 14).

Another factor concerns the interaction between the instructor and the courseware. No courseware can be perfect; there will always be some aspect or problem that could be improved or corrected. Given that CBT instructors will probably be the first to recognize such problems, they play an important role. First, an instructor can provicie feedback to the CBT courseware designers about the problem. Second, an instructor can assure that the students are aware of any courseware problem and that it does not become a barrier. Actually, for minor problems, this situation would be advantageous in that it would give CBT instructors a natural opportunity to interact with the students.

Another issue concerns instructor knowledge of course content. A natural assumption is that the instructor must be knowledgeable about the course material. However, in CBT, the instructor is not the primary source of knowledge; the courseware assumes that role. Consequently, CBT instructors do not have to "know" all there is to know about the material; however, they do have to know the answers to the usual questions the students will ask. After a few classes, these questions will be known.

The same logic holds for knowledge about the CBT system. Over time, the recurring "fixable" problems will become known, and CBT instructors will know how to correct them. Instructors are not expected to fix serious problems in any training delivery system, and such problems should not be an issue in CBT. CBT instructors do not need to be either expert tutors or expert systems analysts.

Another change frequently overlooked during CBT implementation is that any change in a training system may have a greater than anticipated impact on the organization. For instance, Whitney and Urquhart (1990) reported that a two semester project to teach college level mathematics using CBT produced several, unforeseen by-products. Course content chianged as a result of the new computer capability available with CBT. Instructors worked longer and harder than before CBT was adopted. The impact on the CBT project on the departmental budget and support staff was larger than anticipated. A portion of class time had to be devoted to computer operation versus normal course content. For these reasons, plus the fact that the CBT approach did not help the weaker students as much as hoped for, the authors indicated that they would propably not adopt CBT again.

A final issue concerns an argument typically presented as the reason for adopting CBT: the argument that CBT closely approximates the ideal learning situation of a one-on-one tutorial. As sungested above, research shows that students working in either dyads or triads outperform students working alone. Also, current CBT courseware does not approximate what master tutors do (Lepper \& Gurtner, 1989). These results certainly run counter to the one-on-one tutorial argument and suggest that this argument should be dropped as a selling point for CBT.

It might be more accurate to simply argue that, provided all of the issues presented in this paper are attended to, CBT can do a better job than $T I$ in some situations. This approach views CBT as only one of many training delivery systems and permits the course designer to focus on the basic question "Which delivery system is best for my objective?" If CBT is determined to be the best delivery system, the course designer must attend to the issues raised in this paper. If not attended to, the adopted CBT system will either fall or operate at less than an optimal level.

\section{SUMMARY AND RECOMMENDATIONS}

There are known $\mathrm{TI}$ instructor variables which affect achievement. However, not all of these variables remain under the control of the instructor in CBT. To maximize achievement in CBT, effective $\mathrm{TI}$ instructor functions should be provided somewhere in the total CBT environment. The following recommendations are offered for accomplishing this goal. 


\section{Instructors}

CBT instructor selection should focus on individuals who assume responsibility for learning, ensure high time-on-task, and create the proper learning environment/ethos. Moreover, the CBT instructor must be (a) positive, with a can-do/must-do attitude; (b) task-oriented; (c) an internal locus-of-control individual; (d) warm; and (e) somewhat knowledgeable about the subject material and the CBT system.

CBT instructors do not have to be expert in either their field or CBT. The source of motivation for the students will not be the instructors' knowledge. Instead, it will come from the overall achievement attitude created in the classroom.

CBT instructors should also be trained to supervise study teams and to be effective working one-on-one with low-ability students. Instructor preparation should not emphasize presentation skills or course knowledge. Instead, C8T instructor training should emphasize the specifics of the effective CBT environment.

\section{Courseware}

In addition to containing the appropriate principles of course material presentation, CBT courseware should require instructor-student interaction. Because CBT instructors will be spending proportionately more time with low-ability students, a method for quickly assessing student ability level should be incorporated into the courseware. Finally, courseware should be written under the assumption that it will be used by students working in teams.

\section{Environment} ability.

Students should work CBT in dyads or triads. Students should be teamed by like gender and similar

\section{Students}

Students should be prepared in advance on how to work on a computer and how to work in dyad or triad study teams.

\section{Other}

The CBT system should be structured to allow feedback on the courseware from the instructor to the courseware designers.

\section{CONCLUDING COMMENTS}

The behavior and attitude of the instructor in CBT are crucial to both the success of the CBT system and the achievement level attained by the students who use CBT. This paper has emphasized how the role of the instructor and other variables impact student achievement. However, whether or not a CBT system is even implemented is often a function of how well the system is received by in-place instructors. Two of the underlying reasons why the implementation of CBT may be resisted by instructors are (a) the fear of not knowing how they will fit into the new environment, and (b) the fear that they will not retain control of the CBT classroom. I have tried to counter these fears by tying CBT 
to the familiar $\mathrm{TI}$ situation and by providing a detailed account of recognizable factors that must be considered when implementing CBT.

In CBT, instructors are still a vital part of the learning environment, and they still can control the environment. The only real issue for an instructor considering CBT is this: "Is CBT appropriate for my situation?" If the answer is "yes," instructors can use this paper to ascertain the steps they will have to take to ensure that the total CBT environment (to include the instructor) is properly configured to maximize student achievement. 


\section{REFERENCES}

Adams, T.M., Waldrop, P.B., Justen, J.E., \& McCrosky, C.H. (1987, December). Aptitude-treatment interaction in computer-assisted instruction. Educational Technology, pp. 21-23.

Brophy, J.E. (1986, October). Teacher influences on student achievement. American Psychologist, pp. 1069-1077.

Brophy, J.E., \& Good, T.L. (1986). Teacher behavior and student achievement. In M. C. Wittrock (Ed.), Third Handbook of research on teaching (pp. 328-375). "'qw York: Macmillan.

Carrier, C.A., \& Sales, G.C. (1987). Pair versus individual work on the acquisition of concepts in a computer-based instructional lesson. Journal of Computer-Based Instruction, 14, 11-17.

Clark, R.E. (1983). Reconsidering research on learning from media. Review of Educational Research, 53 , 445-459.

Cox, D.A., \& Berger, C.F. (1985). The importance of group size in the use of problem-solving skills on a microcomputer. Journal of Educational Computing Research, 1, 459-468.

Dalton, D.W. (1990). The effects of cooperative learning strategies on achievement and attitudes during interactive video. Journal of Computer-Based Instruction, 17, 8-16.

Dalton, D.W., Hannafin, M.J., \& Hooper, S. (1989). Effects of individual and cooperative computer-assisted instruction on student performance and attitudes. Educational Technology Research and Development, 37, 15-24.

Dossett, D.L., \& Hulvershorn, P. (1983). Increasing technical training efficiency: Peer training via computer-assisted instruction. Journal of Applied Psychology, 68, 552-558.

Hagler, P., \& Knowlton, J. (1987). Invalid implicit assumption in CBI comparison research. Journal of Computer-Based Instruction, 14, 84-88.

Hativa, N., \& Shorer, D. (1989). Socioeconomic status, aptitude, and gender differences in CAl gains of arithmetic. Journal of Educational Research, 83, 11-21.

Hmelo, C.E. (1989). Computer-assisted instruction in health professions education: A review of the published literature. Journal of Educational Technology Systems, 18, 83-101.

Hooper, S., Ward, T.J., Hannafin, M.J., \& Clark, H.T. (1989). The effects of aptitude composition on achievement during small group leaming. Journal of Computer-Based Instruction, 16, 102-109.

Johnson, R.T., Johnson, D.W., \& Stanne, M.B. (1985). Effect of cooperative, competitive, and individualistic goal structures on computer-assisted instruction. Journal of Educational Psychology, 77, 668-677.

Johnson, R.T., Johnson, D.W., \& Stanne, M.B. (1986). Comparison of computer-assisted cooperative. competitive, and individualistlc leaming. American Educational Research Journal, 23, 382-392.

Justen, J.E., Waldrop, P.B., \& Adams, T.M. (1990, July). Effects of paired versus individual user computer-assisted instruction and type of feedback on student achievement. Educational Technology. pp. 51-53.

Klein, J.D., \& Keller, J.M. (1990). Influence of student ability, locus of control, and type of instructlonal control on performance and confidence. Journal of Educational Research, 83, 140-146. 
Lepper, M.A., \& Gurtner, J.L (1989). Children and computers: Approaching the twenty-first century. American Psychologist, 44, 170-178.

McCombs, 8.L., Back, S.M., \& West, A.S. (1984). Self-paced instruction: Factors critical to implementation in Air Force technical training - a preliminary inquiry. (AFHRL-TP-84-23, AD-A145 098). Brooks Air Force Base, TX: Air Force Human Resources Laboratory, Training Systems Division.

McCombs, B.L., \& Lockhart, K.A. (1984). Personnel roles and requirements for non-conventional instruction in Air Force technical training. (AFHRL-TP-84-40, AD-A149 412). Brooks Air Force Base, TX: Air Force Human Resources Laboratory, Training Systems Division.

Moore. B.M. (1988). Achievement in basic math skills for low performing students: A study of teachers' affect and CAI. Journal of Experimental Education, 57, 38-44.

Rosenshine, B. (1983). Teaching functions in instructional programs. The Elementary School Journal, 83, 335-351.

Schofield, J.W., Evans-Ahodes, D., \& Huber, B.A. (1989). Artificial intelligence in the classroom: The impact of a computer-based tutor on teachers and students (Technical Report No. 3). Pittsburgh., PA: University' of Pittsburgh, Learning Research and Development Center.

Shull, B.D. (1990, May/June). Your terminal or mine? Performance and Instruction, pp. 37-39.

Stephenson, S.D. (1989). Computer bassd training (CBT) and academic achievement. Proceedings of the 31st Annual Conference of the Military Testing Association, 304-309.

Stephenson, S.D. (1990a). Design of computer based education software: Maximizing achievement. Proceedings of the 21st Annual Southwest Decision Sciences Institute Conference, 53.

Stephenson, S.D. (1990b). Role of the instructor in maximizing academic achievement in computer-based training. (AFHRL-TP-90-24, AD-A145 143). Brooks Air Force Base, TX: Air Force Human Resources Laboratory, Training Systems Division.

Stephenson, S.D. (1990c). A first look at the role of the instructor in computer based training. Proceedings of the 32nd Annual Conference of the Military Testing Association, 144-149.

Talmage, H., Pascarella, E.T., \& Ford, S. (1984). The influence of cooperative learning strategies on teacher practices, student perceptions of the learning environment, and academic achievement. American Educational Research Journal, 21, $163-179$.

Trowbridge, D., \& Durnin, R. (1984). Results from an investigation of groups working at the computer (NSF Grant No. SED-81 12633). Irvine, CA: California University, Irvine, Educational Technology Center. (ERIC Document Reproduction Service No. ED 238 724).

Warring, D., Johnson, D.W., Maruyama, G., \& Johnson, R. (1985). Impact of different types of cooperative learning on cross-ethnic and cross-sex relationships. Journal of Educational Psychology, 77, 53-59.

Webb, N.M. (1987). Peer interaction and learning with computer in small groups. Computers in Human Behavior, 3, 193-209.

Whitney, R.E., \& Urquhart, N.S. (1990, March). Microcomputers in the mathematical sciences: Effects on courses, students, and instructors. Academic Computing, pp. 14-18, 49-53.

Yager, S., Johnson, D.W., \& Johnson, R.T. (1985). Oral discussion, group-to-individual transfer, and achievement in cooperative learning groups. Journal of Educational Psychology, 77, 60-66. 